\title{
Exploring the Improvement Direction by Analyzing the Degree of Change in the Composition of the Content of Korean National-Level Music Curriculum
}

\author{
Jihyun $\operatorname{Park}^{1}$ \\ ${ }^{1}$ Professor, Department of Music Education, Gwangju National University of Education, Korea, \\ jhp@gnue.ac.kr
}

\begin{abstract}
This study was conducted to derive issues surrounding the 2015 revised music curriculum in Korea and propose a future-oriented music curriculum revision direction that can solve them. Using the content analysis and meta-analysis method, studies related to music curriculum in Korea and abroad were analyzed. According to the results of content analysis, issues and improvement directions in terms of the curriculum content and document system were suggested. First, in terms of the content of the curriculum, the main matters were derived with a focus on core competencies and subject competencies, goal setting, content system composition, teaching and learning and evaluation. Second, in the form of curriculum documents, major issues were reviewed with a focus on the linkage of documents, the linkage of competencies and contents, and the concreteness of the system. As a result of the analysis, the main issues were as follows: ambiguity in the role of competency, lack of musical characteristics, lack of thinking base, lack of practicality, and lack of school presence. In conclusion, improvement directions were suggested to further enhance the competencies of music subject, restructuring the area of music content, supplementing digital teaching and learning, and increasing the readability of documents.
\end{abstract}

Keywords: Music Curriculum, Improvement, Meta-analysis, Content, Document

\section{Introduction}

School music education in Korea has been conducted according to the national curriculum revised by the country. Since the first curriculum was revised and applied in the 1950s, the most recent curriculum was revised and applied in 2015. The curriculum revised in 2015 was improved to emphasize competency building and enhance student diversity and creativity[1]. In particular, competency development is the most important issue in the recent curriculum. This emphasizes the overall cultivation of various knowledge, skills, and attitudes required when living in a changing future society[2]. Self-management capabilities, community capabilities, aesthetic capabilities, information processing capabilities, and creativity-convergence capabilities are representative[3].

As such, the 2015 curriculum has been revised to cultivate learners' competencies and creativity, but there are still limitations in practical terms. For example, the difficulty in selecting the content and method for developing competency, and the lack of practicality in the format of the curriculum document are still challenges to be solved[4-6]. In particular, in recent years, the emphasis on distance classes or non-face-to-face classes by covid-19, etc., has accelerated the need for a new curriculum. In other words, the reality of the digital education situation, which has been referred to as education for future society, has increased[7][8]. Therefore, research on an improved curriculum is required to

Received: September 21, 2020; 1st Review Result: November 09, 2020; 2nd Review Result: December 18, 2020 Accepted: January 25, 2021 
reflect the rapidly changing society and educational situation.

In this regard, the purpose of this study is to propose possible contents of a new curriculum for future-oriented music education. The main contents of research for this are as follows. First, studies related to music curriculum conducted in Korea were meta-analyzed, and studies and data related to music curriculum conducted overseas were compared and analyzed. And the main issues in the current music curriculum in Korea were drawn, and improvement directions to solve these issues were proposed. These study is meaningful in that it provides practical help in revising the curriculum in the future, and in that it is possible to review the current state of education in Korea through comparison with overseas curriculums.

\section{Research Method}

In order to achieve the purpose of this study, the following research methods and procedures were carried out in [Fig. 1]. First, curriculum-related research and data were collected to establish analysis criteria. Researchers analyzed 95 research journals and papers, 32 reports, and 18 curriculum documents, which are materials conducted over the past five years after the revised curriculum was published in 2015. Data was meta-analyzed according to this analysis criterion, and through this, issues of the curriculum were derived. The analysis content was verified through a content validity analysis targeting 3 music education experts, and improvement directions were suggested based on the review results.

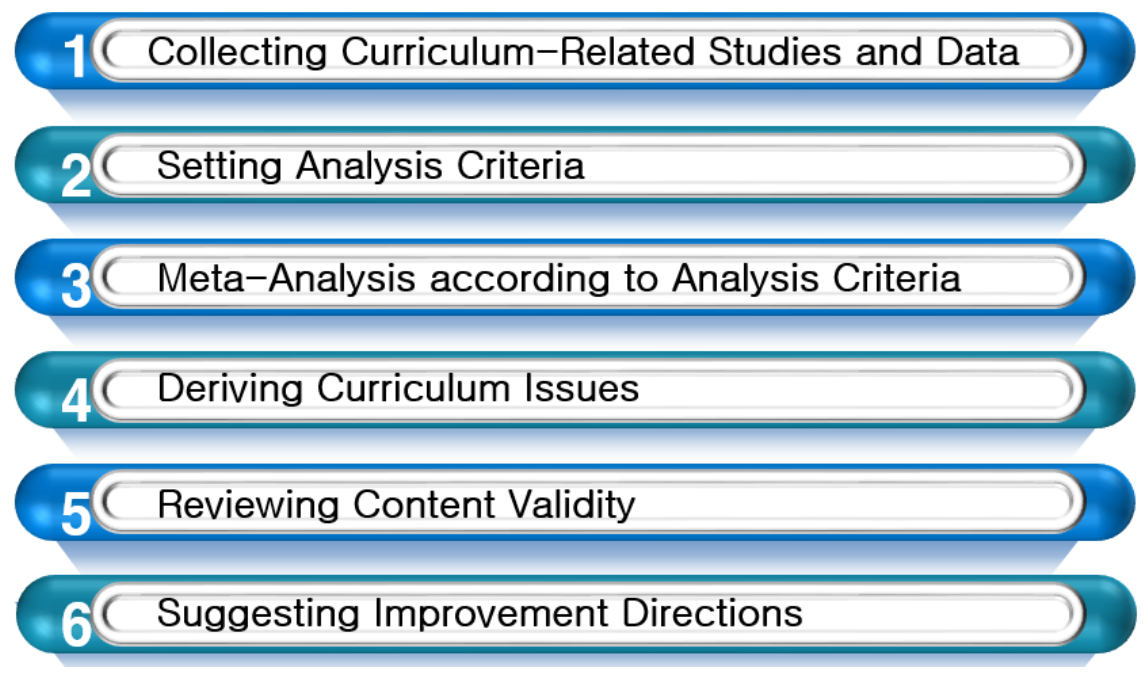

[Fig. 1] Main Research Content and Method

[Table 1] shows the criteria set for meta-analysis. Analysis criteria were set based on the curriculum document items consisting of goals, contents, methods, and evaluation, and viewpoints that have been analyzed most in curriculum studies. There are three main categories:'content' that fills the curriculum, 'document format' as a way of organizing the curriculum, and'theories and perspectives' that are the basis of the curriculum.

[Table 1] Criteria for Meta-analysis

\begin{tabular}{|c|c|}
\hline Analysis criteria & Detailed items \\
\hline Curriculum content & $\begin{array}{r}\text {-Setting the direction, purpose and goal of music subject } \\
\text {-Composition and relationship between core competencies and music subject competencies }\end{array}$ \\
\hline
\end{tabular}




\begin{tabular}{|c|c|}
\hline & $\begin{array}{l}\text {-Content system items and content area composition } \\
\text {-Achievement standards statement and composition, level of competency reflected in the achievement } \\
\text { standards } \\
\text {-Composition and diversity of teaching methods and evaluation }\end{array}$ \\
\hline $\begin{array}{c}\text { Curriculum } \\
\text { Document Format }\end{array}$ & $\begin{array}{l}\text {-Composition and degree of connection of chapters and items } \\
\text {-The relationship between music curriculum documents and other documents } \\
\text {-Formal composition of tables, pictures, icons, etc. } \\
\text {-Degree of relevance between curriculum documents and school sites }\end{array}$ \\
\hline Curriculum theory & $\begin{array}{l}\text {-Major theories and issues related to the curriculum } \\
\text {-Global trends and directions such as OECD } \\
\text {-Perspectives of the composition of the curriculum content: personal and social, sensory-cognitive- } \\
\text { expression, etc. }\end{array}$ \\
\hline
\end{tabular}

\section{Meta-Analysis Results of Previous Studies}

\subsection{Results of Analysis of Research Data in Korea}

Recent studies on the music curriculum that have been conducted in Korea were reviewed. The following [Table 2] summarizes the trends of previous domestic studies[9-13]. In other words, in terms of the content of the curriculum, there were a number of studies on competency, music area, method and evaluation. Subsequently, it can be seen that in terms of the format and system of curriculum documents, many studies have been conducted on tabular formats within documents, linkages between contents, and application to the field. Along with this, many studies have been conducted on the theory and principles of the curriculum, such as understanding-oriented curriculum and curriculum reorganization.

[Table 2] Summary of Domestic Research on Music Curriculum

\begin{tabular}{|c|c|}
\hline Domain & Main Content \\
\hline Curriculum content & - Competency: review and reset, core competencies and music and competencies, competencies and music \\
content
\end{tabular}

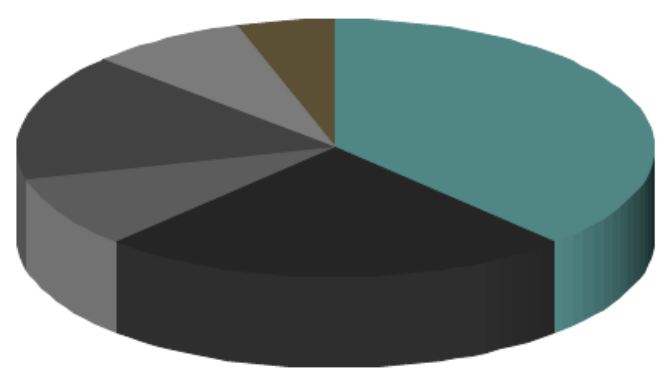

Music competency(38\%)

Practicality(24\%)

Teaching and learning using technoloties(9\%)

Music areas(16\%)

Document system(8\%)

etc. $(5 \%)$

[Fig. 2] Meta-analysis Results of the Most Reviewed Contents in Domestic Music Curriculum Research 
[Fig. 2] shows the most derived results from the analysis results summarized above. The most common study was on what the competencies of music subject were, and the study of how practically the music curriculum was used in the school field was followed. In addition, it was analyzed that there were many studies on whether the areas of music such as expression, appreciation, and everyday life were appropriate, and there were many demands for teaching and learning using technology. In addition, it was analyzed that there was a study on the system and format of curriculum documents.

\subsection{Results of Analysis of Overseas Research Data}

Many foreign countries are implementing competency-oriented music and curriculum. Australia and Singapore offer cross-curricular competencies, while the United States presents unique competencies in music. The analysis of each country's capabilities and main contents is shown in [Table 3] and [Table 4][14-20]. Each country's competencies and main contents were classified by categorizing them into individual internal sense/reflection aspects, individual internal perception/thinking aspects, social communication/expression aspects, and social environment/context aspects.

Music is both an individual musical activity and an activity performed together in society. In this respect, the contents of the curriculum in many countries abroad could be first classified into the perspectives of'individual' and'society'. Among them, from a personal point of view, it was confirmed that the first stage of music was composed of sensory acceptance and reaction, and musical perception and thought that took place after acceptance and reaction. Subsequently, from a social point of view, it was found that musical communication and expression in the community or society, and the environment and context in which such social communication takes place. In short, the music content of most countries was found to emphasize the sensational acceptance of auditory information, cognitive thinking and reflection, and expressing and communicating it together in each context.

[Table 3] Comparative Analysis of Foreign Music and Curriculum Competency and Content (1)

\begin{tabular}{|c|c|c|c|c|}
\hline Category & England & USA & Canada & Singapore \\
\hline $\begin{array}{l}\text { Individual inner } \\
\text { sense/reflection }\end{array}$ & $\begin{array}{l}\text { Improve your own } \\
\text { learning/performance } \\
\text { skills }\end{array}$ & $\begin{array}{c}\text { Synthesis (linkage) of } \\
\text { individual student experiences } \\
\text { with musical ideas/works }\end{array}$ & $\begin{array}{l}\text { Appreciating a } \\
\text { piece of music }\end{array}$ & Self-awareness \\
\hline $\begin{array}{l}\text { Individual inner } \\
\text { cognition/thinking }\end{array}$ & $\begin{array}{l}\text { Problem solving } \\
\text { ability }\end{array}$ & $\begin{array}{c}\text { Conception/development of } \\
\text { new musical ideas/works } \\
\text { (creation) }\end{array}$ & $\begin{array}{l}\text { Creation of a } \\
\text { musical piece }\end{array}$ & $\begin{array}{c}\text { Critical/Creative } \\
\text { Thinking Skills, } \\
\text { Information Technology }\end{array}$ \\
\hline $\begin{array}{c}\text { Social } \\
\text { communication/expression }\end{array}$ & $\begin{array}{l}\text { Communication } \\
\text { Cooperation with } \\
\text { others }\end{array}$ & $\begin{array}{l}\text { Reproduction of musical } \\
\text { idea/work (performance) } \\
\text { Understanding how musical } \\
\text { meaning is conveyed } \\
\text { (reaction) }\end{array}$ & $\begin{array}{l}\text { Playing a piece of } \\
\text { music }\end{array}$ & $\begin{array}{l}\text { Social awareness, } \\
\text { relationship management } \\
\text { Communication }\end{array}$ \\
\hline Social environment/context & · & $\begin{array}{l}\text { Linking (linkage) musical } \\
\text { ideas/works with external } \\
\text { context of music }\end{array}$ & & $\begin{array}{l}\text { Citizen's ability, global } \\
\text { awareness and mutual } \\
\text { cultural skills, } \\
\text { cooperation }\end{array}$ \\
\hline
\end{tabular}


[Table 4] Comparative Analysis of Foreign Music and Curriculum Competency and Content (2)

\begin{tabular}{|c|c|c|c|}
\hline Category & Germany & Australia & New Zealand \\
\hline $\begin{array}{l}\text { Individual inner } \\
\text { sense/reflection }\end{array}$ & $\begin{array}{l}\text { Perception and understanding of music } \\
\text { Listening and understanding music } \\
\text { Musical capacity } \\
\text { Perception capability, reflection capability } \\
\text { Experience and understand music } \\
\text { Personal competence } \\
\text { Self competency, reflection competency }\end{array}$ & Personal ability & $\begin{array}{l}\text { Interpreting in music } \\
\text { Developing musical ideas }\end{array}$ \\
\hline $\begin{array}{l}\text { Individual inner } \\
\text { cognition/thinking }\end{array}$ & $\begin{array}{c}\text { Shaping music } \\
\text { Musical creativity } \\
\text { Make music } \\
\text { Creative use of music } \\
\text { Knowledge acquisition, learning strategy } \\
\text { acquisition } \\
\text { Judge and evaluate }\end{array}$ & $\begin{array}{l}\text { Critical/creative } \\
\text { thinking, } \\
\text { Information and } \\
\text { communication } \\
\text { technology capability }\end{array}$ & $\begin{array}{c}\text { Mastering practical } \\
\text { knowledge of music } \\
\text { Communication/interpretation } \\
\text { in music }\end{array}$ \\
\hline $\begin{array}{c}\text { Social } \\
\text { communication/expression }\end{array}$ & $\begin{array}{c}\text { Social competence } \\
\text { Musical reproduction capacity } \\
\text { Communicating about music } \\
\text { Music and movement } \\
\text { Expressive competence, action competency } \\
\text { Communication skills }\end{array}$ & Literacy, social skills & $\begin{array}{c}\text { Understanding Music/Sound } \\
\text { Arts in Context }\end{array}$ \\
\hline Social environment/context & $\begin{array}{l}\text { Understanding music culture } \\
\text { Formation of cultural and historical } \\
\text { dimension }\end{array}$ & $\begin{array}{l}\text { Intercultural } \\
\text { understanding }\end{array}$ & $\begin{array}{c}\text { Understanding Music/Sound } \\
\text { Arts in Context }\end{array}$ \\
\hline
\end{tabular}

\section{Analysis Results of Issues in Music Curriculum}

\subsection{Results in Terms of Curriculum Content}

Issues related to the contents of the curriculum can be summarized as follows [Table 5]. And [Fig.3] is an analysis of the most frequently mentioned content among the issues in order of frequency.

[Table 5] Results in Terms of Curriculum Content

\begin{tabular}{|c|c|}
\hline Category & Main Issues \\
\hline \multirow{3}{*}{$\begin{array}{l}\text { Core competencies and subject } \\
\text { competencies }\end{array}$} & Ambiguity in the role of core competencies and subject competencies \\
\hline & Non-reflection of subject characteristics \\
\hline & Simple listing structure of competencies \\
\hline \multirow{2}{*}{ Goal setting } & Lack of future-oriented communication \\
\hline & Lack of linkage fusion \\
\hline \multirow{4}{*}{ Contents System Composition } & Specific genre-oriented composition \\
\hline & Lack of thought-based content \\
\hline & Lack of interaction \\
\hline & Lack of diversification of everyday life \\
\hline \multirow{3}{*}{$\begin{array}{c}\text { Teaching and Learning } \\
\text { \& Evaluation }\end{array}$} & Emphasis on practical skills \\
\hline & Insufficient use of technology \\
\hline & Lack of specificity of various evaluations \\
\hline
\end{tabular}


First, in the core competency and goal section, the relationship and connection between common core competencies and music subject competencies must be presented, and music subject competencies reflecting musical characteristics and values must be supplemented. In addition, it is required to deviate from the parallel listing of competencies and to establish a hierarchy and structure between competencies such as key competencies, and consider a more macroscopic perspective, such as participation in real life or well-being in consideration of future sustainable life. Furthermore, the fusion of links between other arts and subjects along with musical value should be presented more practically.

Second, in the content system and composition part, it is necessary to emphasize the understandingoriented performance of core concepts deviating from specific genres or types such as Korean traditional music. In addition, content that can improve individual problem-solving and creative thinking skills is needed, freeing from inner music activities such as expression and appreciation. In addition, beyond individual musical expressions, interaction aspects such as reaction, context, communication, interpretation, and connection should be more emphasized, and various music contributions and ethical issues should be covered.

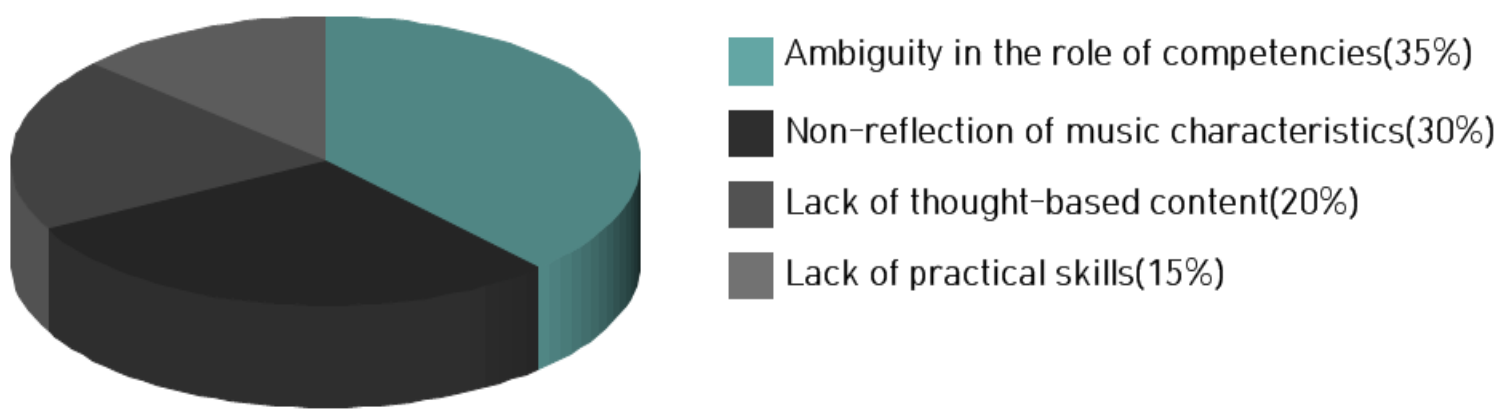

[Fig. 3] Major issues related to curriculum content

Moreover, in teaching and learning and evaluation, it is necessary to diversify teaching and learning, and evaluation, which deviates from practical evaluation. In addition, methods for teaching and learning, and evaluation in preparation for the new era, such as online classes and the use of technology, are required. In addition, concreteness in student-centered teaching and learning or process-oriented evaluation is required.

\subsection{Results in the Curriculum Documentation System}

[Table 6] shows the results of analyzing major issues related to the format and system of curriculum documents. In addition, [Fig. 4] presents the major issues related to the curriculum document system in order of frequency. Since competencies and content systems are not connected, a composition that links competencies-contents-achievement criteria-teaching learning-evaluation, etc. is necessary. In addition, it should be structured so that the connection between other documents and music, and the connection between grade and school level, etc. In addition, since terms such as core concepts, generalized knowledge, and skills are ambiguous, clear terms should be used. Finally, there is a need to pay attention to teaching-learning in the school field or to the composition of practical documents that help teachers understand. 
[Table 6] Results in the Curriculum Documentation System

\begin{tabular}{|c|c|}
\hline Category & Main Issues \\
\hline Chapter-section linkage & Ambiguous link between competency and content \\
\hline Music and other documents & Need to supplement document linkage \\
\hline Table, picture, etc. & System ambiguity \\
\hline Document and Field & Lack of applicability in school \\
\hline
\end{tabular}

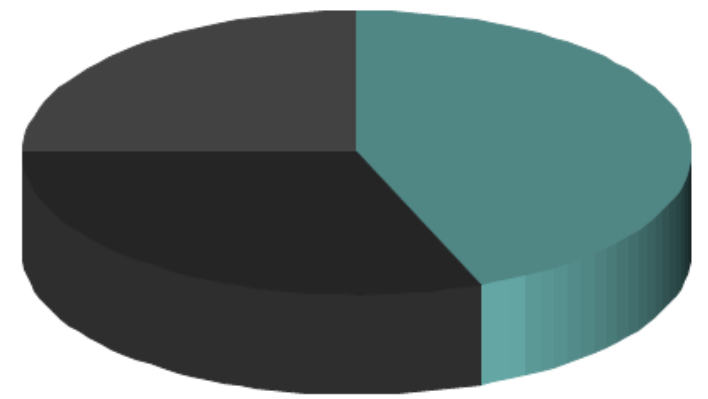

Content system item modification(44\%)

Including pictures and icon(31\%)

School applicability(25\%)

[Fig. 4] Major Issues Related to Documentation System

\section{Discussion and Conclusion}

Based on the results of meta-analysis of many studies conducted after the 2015 revised curriculum notification in Korea, the major issues of the music curriculum were analyzed and derived. [Table 7] shows a proposal for future-oriented improvement directions to solve the above-described issue results.

[Table 7] Proposal of Future-oriented Music Curriculum Revision Direction

\begin{tabular}{|c|c|}
\hline \multirow{2}{*}{ Category } & Improvement \\
\hline \multirow{2}{*}{ Contents } & Composition of musical capabilities such as acceptance, expression, and cultural community \\
\cline { 2 - 3 } & Presenting music content that connects with music competency \\
\cline { 2 - 2 } Methods & Restructuring the music content area through reaction, idea, expression, reflection, and connection \\
\hline Documents & Digital music literacy-based teaching and learning method and evaluation supplement \\
\hline
\end{tabular}

First, suggestions for improvement in terms of content are as follows. It is necessary to establish a music curriculum competency that reflects the characteristics of music while considering the sustainable life of the future and present its structure and hierarchy. In addition, it is necessary to present the music content and elements corresponding to each competency together so that the competency is specifically linked to the music content. In other words, acceptance, expression, and 
cultural community can be presented as major competencies. And acceptance can consist of connecting with music contents such as music appreciation or sensory understanding. In addition, it is necessary to deviate from the composition of the domain of inner music activities such as performance, song, and creation, and constitute a new domain. For example, it can be oriented toward constructing thought-based domains such as reacting, conceiving ideas, expressing and communicating, reflecting and interpreting, and connecting.

Second, suggesting the improvement direction in terms of method is as follows. Contents that can maximize the convenience of music learning through various digital applications such as technology and networks should be included in the music curriculum. At the same time, it should be configured to emphasize high-quality digital literacy based on artistic sensitivity. Furthermore, various and practical teaching and learning methods and evaluations should be included in the curriculum documents, and students' self-directed learning and collaborative learning with peers should be carried out from various angles.

Finally, from the formal aspect of the curriculum document, it is necessary to take care to make the document highly readable by using pictures or icons. Above all, it should be able to be a document system that provides practical help when teachers reorganize the curriculum. In other words, other than the main content, explanations, specific examples, various learning activities, and teacher guidelines can be supplemented in the curriculum document.

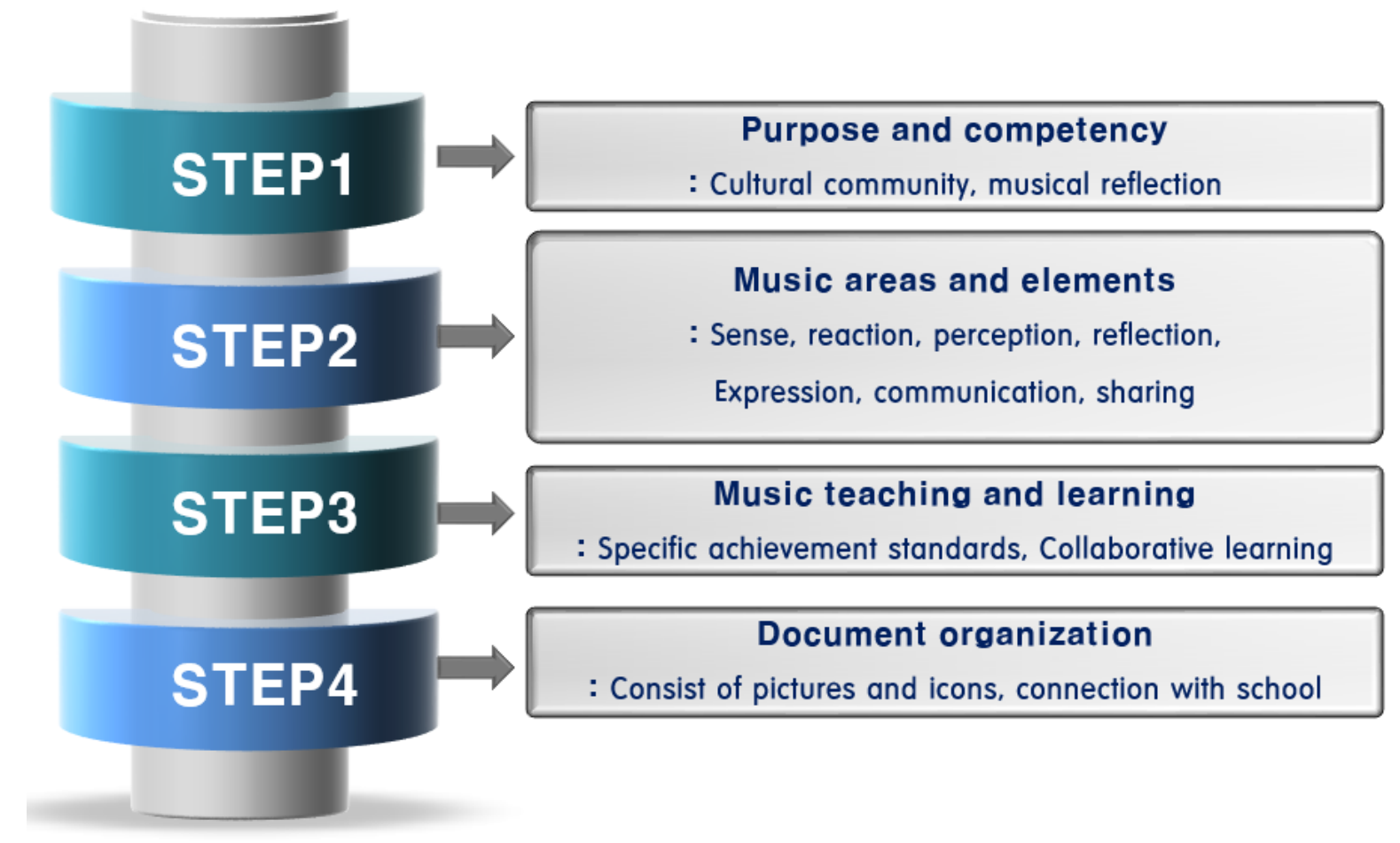

[Fig. 5] The process of building a new music curriculum

The improvement directions discussed above should be discussed in more detail through the process presented in [Fig. 5]. In other words, it is necessary to discuss the direction of music education based on cultural community and musical reflection, and establish a music curriculum competency to go in this direction from the viewpoint of musical expression and cultural expression. In addition, it is necessary to subdivide the viewpoints of musical expression and cultural expression into sensereaction-perception-reflection-expression-communication-sharing, etc. These subdivided areas are stated as specific achievement standards so that they are practically helpful in school instruction. All 
the contents mentioned above should be clearly indicated with pictures and icons to enhance the readability of the curriculum documents.

The researcher analyzed what the main issues were in the music curriculum in Korea and reviewed how to improve these issues from various angles. This is meaningful in that it provides practical help when revising a new curriculum. However, it will be more meaningful only after the following various studies are conducted. A detailed study is needed on what content should be improved by elementary, middle, and high school. In addition, a study on the appropriateness of the curriculum is required to determine how specifically or broadly it is appropriate to present the improvement contents. In addition, it is necessary to systematically analyze the needs of the school field and discuss the document system reflecting this in detail.

\section{References}

[1] H. Y. Han, S. G. Park, A Study on the Correlations of Self-Esteem, Self-Efficacy, and Learning Motivations of Underachieving Elementary School Students, Asia-pacific Journal of Convergent Research Interchange, (2020), Vol.6, No.8, pp. 79-89.

[2] J. H. Park, Investigating Students' Perception of Subject Selection in the Organization of High School Elective Curriculum, Asia-pacific Journal of Convergent Research Interchange, (2020), Vol.6, No.9, pp. 91-98.

[3] S. H. Kim, A Study to Improve Student Service-learning: From Activity to Learning, Asia-pacific Journal of Convergent Research Interchange, (2020), Vol.6, No.6, pp. 65-72.

[4] J. H. Song, A Study on the Music Subject Competency in the School Music Education, Music Education Research, (2015), Vol.44, No.4, pp.117-146, UCI : G704-001377.2015.44.4.001

[5] J. H. Park, Comparative analysis of competencies presented in OECD education 2030 and 2015 revised music curriculum: Focusing on the degree of reflection of competency, Korean Journal of Research in Music Education, (2019), Vol.48, No.4, pp.161-180.

[6] J. H. Park, Analysis of 2015 revised music curriculum in Korea, Journal of Education and Social Science, (2020), Vol.1, No.1, pp.23-28.

[7] B. P. McLain, Scott Shuler's "Music and Education in the Twenty-First Century: A Retrospective"-Review and Response, Arts Education Policy Review, (2014), Vol.115, No.1, pp.12-18, https://doi.org/10.1080/10632913.2014.847354

[8] OECD, CCM Main Study: Revised Proposal for Curriculum Content Mapping, Unpublished, (2018)

[9] J. H. Park, S. Y. Yang, The Development of a Textbook Model for Enhancing the Music Competency in the Music Curriculum, Korean Journal of Research in Music Education (2018), Vol.47, No.1, pp.105-125.

[10] N. Y. Choi, Reconstructing the National Music Curriculum towards Enduring Understandings: Cases of Elementary Teachers, The Journal of Elementary Education, (2016), Vol.29, No.1, pp.125-150, UCI : G704000649.2016.29.1.002

[11] D. C. Ju, Structural Characteristics of Recent German Curricula for Music Class, Korean Journal of Research in Music Education, (2019), Vol.48, No.4, pp.223-251.

[12] M. J. Yoon, An Comparative and Analytic Study of Music Curriculum between Korea and Australia based on Multicultural Education Perspectives, The Journal of Future Music Education, (2018), Vol.3, No.1, pp.49-64, DOI : 10.36223/jnafme.2018.3.1.003

[13] E. J. Lim, A study on the content system of art curriculum, Korean Journal of Research in Music Education, (2020), Vol.49, No.1, pp.175-203.

[14] Department for Education, National Curriculum: Music programmes of study: key stage 1-2, https://assets. publishing.service.gov.uk/government/uploads/system/uploads/attachment_data/file/239037/PRIMARY_national_cu 
Exploring the Improvement Direction by Analyzing the Degree of Change in the Composition of the Content of Korean NationalLevel Music Curriculum

rriculum_-_Music.pdf, (2013)

[15] National Coalition for Core Arts Standards, National Core Arts Standards: Dance, Media Arts, Music, Theatre And Visual Arts 2014, http://www nationalartsstandards.org, (2014).

[16] Ontario Curriculum, The arts: Grades 1-8, http://www.edu.gov.on.ca/eng/curriculum/elementary/arts18b09curr.pdf, (2009)

[17] Student Development Curriculum Division, Music Teaching and Learning Syllabus: Primary \& Lower Secondary, Ministry of Education, Singapore, https://www.moe.gov.sg/docs/default-source/document/education/syllabuses/artseducation/files/2015_Music_Teaching_and_Learning_Syllabus_(Primary_and_Lower_Secondary).pdf, (2016)

[18] Education Server Berlin-Brandenburg, Musik Jahrgangsstufen 1-10, https://bildungsserver.berlin-brandenburg. de/fileadmin/bbb/unterricht/rahmenlehrplaene/Rahmenlehrplanprojekt/amtliche_Fassung/Teil_C_Musik_2015_11_1 6_web.pdf, (2017/2018)

[19] ACARA, Australian Curriculum, https://www.australiancurriculum.edu.au/download?view=f10, (2015)

[20] New Zealand Ministry of Education, The New Zealand Curriculum, https://nzcurriculum.tki.org.nz/The-NewZealand-Curriculum\#collapsible1, (2007) 